\title{
The impact of smog on the concentration of particulate matter in the antelope house in the Silesian zoological garden
}

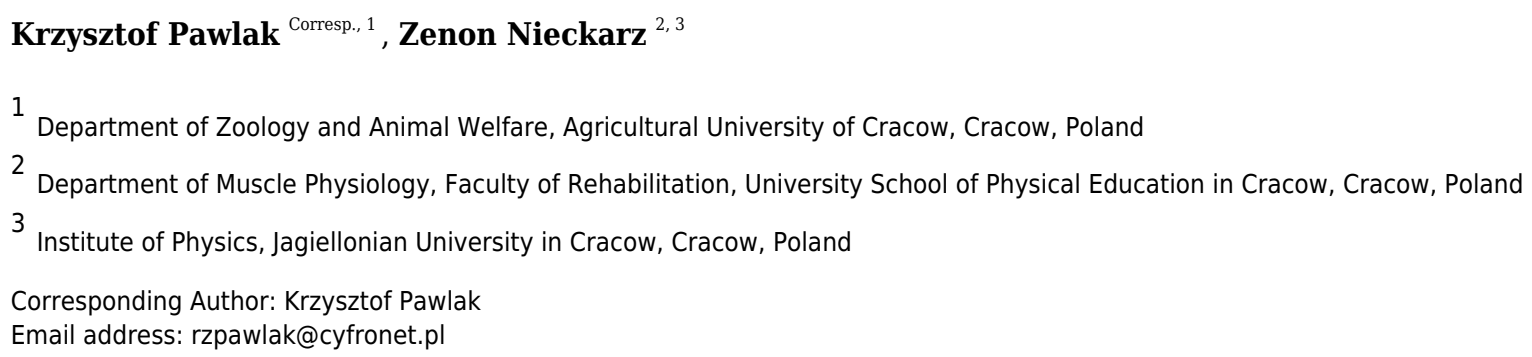

Persistent negligence in the field of environmental protection in Poland as well as strong dependance of the energy sector on the fossil fuels have led to serious pollution of the air with particulate matter, which at high concentrations is capable of penetrating into the buildings. The aim of this paper is to assess the impact of particulate airborne pollution on the concentration of particulate matter inside the antelope house in the Silesian Zoological Garden located within the Upper Silesia in Poland. The research was conducted from February to May in 2018. The records taken in the research period show that the concentration of PM10 exceeded the level of $50 \mu \mathrm{g} / \mathrm{m} 3$ outside the building during 26 days and 11 days when it comes to the concentration of particulate matter inside the antelope house. The quantity of particulate matter in the antelope house is strongly correlated with the concentration of the particles in the air. Despite fitting existing ventilation system with a filter that reduces the dust level by $60 \%$ during the highest level of smog, particulate matter concentration in the antelope house exceeded acceptable limit for PM10 more than twofold. Particle size-fraction analysis revealed that as much as $85 \%$ of the particles detected in the studied compartment constitute PM2.5. 


\section{The Impact of Smog on the Concentration of Particulate Matter in the Antelope House in the Silesian Zoological Garden}

Krzysztof Pawlak ${ }^{1}$, Zenon Nieckarz ${ }^{2,3}$

${ }^{1}$ Department of Zoology and Animal Welfare, Faculty of Animal Science, University of Agriculture in Cracow, Poland

${ }^{2}$ Department of Muscle Physiology, Faculty of Rehabilitation, University School of Physical Education, Cracow, Poland

${ }^{3}$ Experimental Computer Physics Department, Institute of Physics, Jagiellonian University in Cracow, Poland Corresponding Author: Krzysztof Pawlak ${ }^{1}$

Al. Mickiewicza 24/28, Krakow, 30-059, Poland

Email address: rzpawlak@cyfronet.pl

\section{Abstract}

Persistent negligence in the field of environmental protection in Poland as well as strong dependance of the energy sector on the fossil fuels have led to serious pollution of the air with particulate matter, which at high concentrations is capable of penetrating into the buildings. The aim of this paper is to assess the impact of particulate airborne pollution on the concentration of particulate matter inside the antelope house in the Silesian Zoological Garden located within the Upper Silesia in Poland. The research was conducted from February to May in 2018. The records taken in the research period show that the concentration of PM10 exceeded the level of $50 \mu \mathrm{g} / \mathrm{m}^{3}$ outside the building during 26 days and 11 days when it comes to the concentration of particulate matter inside the antelope house. The quantity of particulate matter in the antelope house is strongly correlated with the concentration of the particles in the air. Despite fitting existing ventilation system with a filter that reduces the dust level by $60 \%$ during the highest level of smog, particulate matter concentration in the antelope house exceeded acceptable limit for PM10 more than twofold. Particle size-fraction analysis revealed that as much as $85 \%$ of the particles detected in the studied compartment constitute PM2.5.

\section{Introduction}


32 Sulfurous smog, also called London smog, is produced in humid air that is strongly polluted with 33 acidic gases, mainly with sulfur dioxide $\left(\mathrm{SO}_{2}\right)$, carbon dioxide $\left(\mathrm{CO}_{2}\right)$, nitric oxide (NO) and particulate matter (Polivka 2018; Poulopoulos SG. 2016). Particles with the diameter exceeding $2.5 \mu \mathrm{m}$ that are present in smog are generated as a result of mechanical actions, such as grinding or crushing various types of materials (WHO, 2006). These materials either occur naturally mineral dust, sea salt, or represent anthropogenic substances - produced as a consequence of tire and brake abrasion. Fine particulate matter particles, with the diameter below $2.5 \mu \mathrm{m}$, is formed mainly through the burning of fossil fuels in the utilities sector (Seinfeld \& Pandis, 2006). Particles present in smog contain metal oxides, acidic condensates, heavy and transition metals (Wróbel et al. 2000), sulfates and nitrates, as well as elemental and organic carbon (Routledge \& Ayres 2005).

Health and the quality of life, both human and animal, is tightly connected with the condition of the environment. It is assumed that airborne particulate pollution constitutes one of ten most significant threats to global health (Lim et al. 2012). The research into the impact of smog on living organisms revealed that particle pollutants increase the risk of developing asthma and allergy (Chen et al. 2018), cause arrhythmia (Hazari et al. 2009), lung cancer (Pope et al. 2002), chronic obstructive lung disease (Zanobetti et al. 2008), bronchitis (King et al. 2018), as well as decrease fertility (Selevan et al. 2000, Yi et al. 2017) and constitute a risk factor for abnormal fetal development (Perera et al., 2002).

Prolonged ignorance as to the environmental conservation in Poland as well as heavy reliance of the energy industry on fossil fuels resulted in substantial increase in the particulate air pollution (www.gios.gov.pl; Tainio et al., 2013) This problem is especially serious in the Upper Silesian Agglomeration where acceptable 24-hour PM10 concentration is exceeded 67 to 102 days per one year (Raport 2018).

The research conducted by Massey et al. (2009) and Chen et al. (2016) demonstrated that when air pollution is heavy particles are capable of migrating into the buildings. This problem becomes even more serious in the case of facilities intended for animals where particles penetrate as a result of permeability of the construction as well as through supply ventilation, which constitutes a regular and indispensable element of proper equipment in animal facilities. During winter, when the incidence of smog greatly increases, flow rate for the air exchanged by one 
62 animal may amount to as much as $100 \mathrm{~m}^{3} / \mathrm{h}$ (Magrin et al. 2017). The problem of excessive 63 particulate pollution concerns not only livestock but also zoo animals and it worsens in autumn

64 and winter months as animals from tropical and subtropical climates spend most of that time inside buildings. Well-being of these animals depends heavily on microclimate inside buildings where they stay (Veasey 2017). By disturbing reproductive system airborne particle pollutants can decease the number of healthy offspring (Selevan et al. 2000; Perera et al., 2002), and as a consequence severely hamper or even prevent the process of saving threatened species - one of the main tasks undertaken by zoological gardens.

Available literature does not contain papers dealing with the influence of smog on the microclimate of buildings intended for animals, especially when it comes to zoological gardens. Existing research focuses on the impact of the particles generated as a result of animal production on employees handling animals or involved in degradation of the external environment (Mołocznik 2004; Hulin et al. 2015).

As far as the impact of particulate matter on animals kept in the zoos is concerned, careful attention should be focused on antelopes as their high oxygen efficiency and lung capacity make them especially vulnerable to particulate pollution (Hinchcliff et al. 2008; Stafford \&Stafford 1993).

This paper is concerned with assessing the impact of particulate air pollution on the concentration of PM10 and PM2.5 in the antelope house located in the Silesian Zoological Garden in Chorzów.

\section{Materials \& Methods}

The research was conducted during the coldest period in 2018, that is between 27.02.2018 and 16.05.2018 (79 days) in the building housing antelopes located in the Silesian Zoological Garden in Chorzów (Fig. 1). The Zoological Garden is located on the border of Chorzów (108 thousand citizens) and Katowice (302 thousand citizens). This object constitutes a part of the Silesian Park. It is surrounded with forest complexes from the north and east. According to the records taken between 2014 and 2017 by the monitoring station of the Voivodship Inspectorate of Environmental Protection, located $2400 \mathrm{~m}$ away from the Zoological Garden, there were 290 days when the limit value for PM10 was exceeded (Raport 2018). 
91 Field experiments were approved by Silesian Zoological Garden in Chorzów (agreement number $92 \mathrm{C} / 21 / 2013 / \mathrm{WHiBZ}$ ). During taking measurements the building was occupied by 19 antelopes: 93 Defassa waterbucks (Kobus ellipsiprymnus) - 7 pieces weighing between 112 and $142 \mathrm{~kg}$, 94 addaxes (Addax nasomaculatus) - 5 pieces with the weight ranging from 85 to $118 \mathrm{~kg}$ and 95 lowland nyalas (Tragelaphus angasii) - 7 pieces weighing 65 to $120 \mathrm{~kg}$. Throughout the entire experimental period the animals stayed indoors, inside the boxes, with the possibility to move to 97 the adjacent box only. Cleaning and litter replacement occurred once daily in the morning between 7:00 and 9:00.

Cubic volume of that building amounts to $3626 \mathrm{~m}^{3}$, maximum height to $5,2 \mathrm{~m}$ and minimum height to $3,7 \mathrm{~m}$. Total floor space of boxes amounts to $319 \mathrm{~m}^{2}$ (floor space of a single box for boxes no. 1-7 amounted to 11,5 m2, while for boxes no. 8-20 to $25 \mathrm{~m}^{2}$; Fig.2, Fig. 3). Animal boxes are provided with rubber flooring covered with long wheat straw with approximately $8 \%$ moisture content. The floor in the areas used by the visitors and passageways is covered with industrial flooring. The building is equipped with a mechanical supply-exhaust ventilation system, type Golem 4 with the capacity of $10000 \mathrm{~m}^{3}$ per hour with class F6 filters. Specific fan 106 power of supply air fans amounted to $1,33 \mathrm{~kW} / \mathrm{m} 3 / \mathrm{s}$, while SFP for exhaust air fans to 1,02 $\mathrm{kW} / \mathrm{m} 3 / \mathrm{s}$. Air flow rate in the supply air ducts reached $2,46 \mathrm{~m} / \mathrm{s}$, while in the exhaust air ducts $1,94 \mathrm{~m} / \mathrm{s}$. Air circulation in the studied building was assessed based on air flow measurements taken using a device Testo 425 (Testo Polska; resolution $0,01 \mathrm{~m} / \mathrm{s}$, accuracy $0,03 \mathrm{~m} / \mathrm{s}$ ).

110 Existing ventilation system provides only preliminary air filtration through a pocket filter (G4 $592 \times 592 \times 360 \mathrm{~mm} 6 \mathrm{k} / \mathrm{metal}$ ), that filtrates the fractions with the size exceeding 10 um with $70 \%$ efficiency. Therefore, $30 \%$ of the particulate matter sized 10 um migrates inside the building and the fractions with smaller diameter are filtrated to a lesser degree (negligible scope). The ventilation operates 24/7. The ventilation system was not cleaned during taking measurements. The ventilation is cleaned twice yearly in the first week of February and July.

The study covered the following measurements: air temperature, relative air humidity, air 117 pressure as well as the concentration of PM10 and PM2.5. The measurements were taken using 118 two university measuring stations (UMS, serial no. U32 and U33, Poland) developed within the framework of the Storm\&DustNet project implemented at the Jagiellonian University in Krakow. 
121 the second was fitted outside $2 \mathrm{~m}$ above the ground at the distance of $30 \mathrm{~m}$ from the studied

122 facility (Fig 1, Fig. 2.). The device is fitted with a laser detector SEN0177 (DFRobot, China)

123 that enables measuring the concentration of PM10 and PM2.5 in the air. The measurements of

124 particle concentration and other parameters are taken continuously and the records of average

125 values are compiled every minute. The accuracy of the particulate matter detector was verified

126 by comparing data recorded during previous test measurements with the readings obtained from

127 the reference station EDM107 belonging to GRIM company (Grimm \& Eatough 2009). The

128 measurement error for EDM107 station amounts to $\pm 2 \mu \mathrm{g} / \mathrm{m} 3$. This device has obtained a 129 certificate of calibration and equivalency to a gravimetric method (Grimm \& Eatough 2009).

130 Comparative measurements included natural ambient air and various particulate matter 131 concentrations. The comparison revealed that measurements for PM2.5 and PM10 in UMS 132 stations are encumbered with an error that does not exceed $\pm 9 \mu \mathrm{g} / \mathrm{m} 3$. Measurements of the air 133 temperature, humidity and pressure were taken using a BME detector fitted into the UMS station 134 (temperature - measuring range from -40 to $+85{ }^{\circ} \mathrm{C}$, accuracy: $\pm 1{ }^{\circ} \mathrm{C}$; humidity - measuring 135 range from 10 to $80 \% \mathrm{RH}$; accuracy: $\pm 3 \% \mathrm{RH}$; air pressure - measuring range from 300 to $1361100 \mathrm{hPa}$, accuracy: $\pm 1 \mathrm{hPa}$ ).

137 UMS stations measure PM concentrations and other parameters several dozen times per minute. 138 Then the average minute values are computed. Later minute values are sent to the server and 139 saved to a database. In the subsequent analyses average minute values are the basis for 140 calculating average hourly and daily values.

142 Statistical analyses

143 Statistical analyses were performed using OriginPro 2016 software (OriginLab 144 Corporation, Northampton, MA, USA). Normality distribution for variables was tested using the 145 Shapiro-Wilk test. Due to the fact that obtained measurement results have no normal distribution, 146 they were analyzed employing Spearman's rank correlation coefficient (RS) with determining 147 significance level ( $p$-value). A 2-tailed test of significance was used in all studied cases. 
149 Air flow rate measured in the antelope house during the experiment ranged between $0,14 \mathrm{~m} / \mathrm{s}$ and $1500,18 \mathrm{~m} / \mathrm{s}$.

151 Daily average concentrations for PM10 and PM2.5 were determined based on particulate matter 152 measurements. Distribution of these PM levels is shown in Fig. 4 and Fig. 5, respectively.

153 The measurements indicated that daily average concentration of $50 \mu \mathrm{g} / \mathrm{m}^{3}$ outside the building 154 within the studied period was exceeded during 26 days.

155 The highest daily average concentration for PM10 in the air was recorded on 6th March 2018 $156\left(273 \mu \mathrm{g} / \mathrm{m}^{3}\right)$.

157 Measurements taken inside the building indicted that in the studied period there were 11 days 158 when the level of $50 \mu \mathrm{g} / \mathrm{m}^{3}$ was exceeded. The highest indoor daily average for PM10 was also 159 recorded on 6th March and it amounted to $118 \mu \mathrm{g} / \mathrm{m}^{3}$. The concentration for PM10 outside the 160 building was almost always higher than the one recorded indoors. We documented only two 161 instances (19th April and 7th May) when the quantity of particulate matter inside the antelope 162 house was higher by $1 \mu \mathrm{g} / \mathrm{m}^{3}$ than outside. However, it must be pointed out that these differences 163 are significantly lower that the measurement error. Spearman's correlation coefficient (RS) 164 computed for the entire study period indicated a strong correlation ( $p$-value $<0.01)$ between the 165 concentration of PM10 inside and outside the building $(\mathrm{RS}=+0,91)$.

166 The distribution of daily average concentrations for PM2.5 for the studied period is shown in 167 Fig. 3. According the measurements, in the studied period there where 35 days when the level of 168 particulate matter outside the building exceeded $25 \mu \mathrm{g} / \mathrm{m}^{3}$ and 24 days when it comes to records 169 taken indoors. The highest daily average concentration for PM2.5 was reached on 6th March $170\left(245 \mu \mathrm{g} / \mathrm{m}^{3}\right.$ outside the building and $100 \mu \mathrm{g} / \mathrm{m}^{3}$ indoors). The concentration of PM2.5 inside the 171 building has never exceeded the level recorded in the ambient air. Statistical analysis $(\mathrm{RS}=+0.93)$ 172 revealed a strong correlation ( $p$-value $<0.01$ ) between the concentration of PM2.5 in the 173 atmospheric air and inside the antelope house.

174 Statistical analysis showed a strong correlation between the concentration of PM10 and PM2.5 175 both inside and outside the building.

176 Spearman's correlation coefficient (RS) between PM10 and PM2.5 outside and inside are large 177 and indicate full dependence.

178 Calculation of the ratio for PM2.5 to PM10 concentration inside and outside the antelope house 179 resulted in obtaining very similar values ( 0.84 and 0.85 , respectively).

180 Daily reduction factor (RF) for the entire research period for PM10 was calculated according to 181 Eq. 1, and the distribution in time for this factor is shown in Fig.6.

$182 R F=\frac{P M_{\text {outdoor }}-P M_{\text {indoor }}}{P M_{\text {outdoor }}} \times 100 \quad$ Eq. 1 
184 The calculations revealed that high value for reduction factor (RF) occurred between 1st and

185

186

187

188

189

190

191

192

193

194

195

196

197

198

199

200

201

202

203

204

205

206

207

208

209

210

211

212

213

214

215

216

217 10th as well as between 13th and 19th March and ranged between 50\% and 65\%, while on 26st April it reached $86 \%$.

Figures 7 and 8 illustrate average daily distribution of hourly values for PM10. In the case of Figure 7 the analysis was conducted for the period with high PM content in the atmospheric air (27.02.2018-03.04.2018). The Figure 8 refers to the period when the level of particulate matter in the air was low $(04.04 .2018-16.05 .2018)$.

It has been observed that both in the case of high (Fig. 7) and low (Fig. 8) PM content in the atmospheric air, the concentration of particulate matter inside and outside the building followed the same pattern. The only differences were recorded between 7:00 and 9:00.

Analysis of the high frequency data -1 min (Fig. 9) revealed that the change in the PM concentration outside the building resulted in the shift in PM concentration indoors that was delayed only by $14 \mathrm{~min}$. This delay was identified during establishing the maximum Spearman's correlation coefficient as a function of time shift between PM10 distribution measured indoors and outdoors. There is no doubt that it was caused by a mechanical air supply system that operates round-the-clock. As shown in Fig. 9, the distribution of PM concentration outdoors (red line) is irregular and changeable, while the one for indoor PM concentration (black line) is more regular. Irregular distribution of PM outdoors is connected with the changes in air direction and flow rate (wind).

Daily average temperature outside the building ranged from $-5^{\circ} \mathrm{C}$ to $27^{\circ} \mathrm{C}$, while the temperature inside the antelope house was in the range of $17^{\circ} \mathrm{C}$ to $27^{\circ} \mathrm{C}$. The distribution of daily average temperatures in described period is shown in Fig. 10.

Statistical analysis revealed a strong correlation between average hourly temperatures outside and inside the studied building $(\mathrm{RS}=+0.88)$. Relative air humidity measured outside the building reached the values from $39 \%$ to $68 \%$, while inside it ranged from $20 \%$ to $52 \%$ (Fig. 11 ).

Atmospheric pressure in the studied period ranged between $965 \mathrm{hPa}$ and $1000 \mathrm{hPa}$ (Fig. 12).

Correlation coefficient between average hourly humidity inside the antelope house and humidity in the ambient air amounted to $\mathrm{RS}=+0.40$.

The calculations indicated a strong negative correlation between thermal conditions outside the antelope house and the concentration for PM2.5 and PM10 inside the building (RS: -0.62 and 0.63 , respectively). We discovered a weak correlation between relative humidity outdoors and the concentration of PM10 and PM2.5 inside the building (RS: +0.35 and +0.39 , respectively), as well as a weak correlation between atmospheric pressure and the concentration for PM2.5 and PM10 inside the antelope house $(\mathrm{RS}=-0.31)$.

PeerJ reviewing PDF | (2019:11:42758:2:0:NEW 31 Mar 2020) 
218

219

220

221

222

223

224

225

226

227

228

229

230

231

232

233

234

235

236

237

238

239

240

241

242

243

244

245

246

247

248

249

250

251

252

253

254

255

\section{Discussion}

The basic function of a building is to provide people and animals with as good as possible living conditions. Buildings intended for animals shall be equipped with a ventilation system that removes used air and supplies atmospheric air (Collins 1990). When the air outside is heavily polluted, the ventilation, despite improving the quality of the air inside the building, contributes to increasing pollutant levels indoors (Qi et. al. 2017). The measurements taken in the course of the study indicated that during the period of high dust loading in the ambient air, high concentration of particulate matter also occurs inside the antelope house. Unfortunately, available materials fail to provide standards for permissible exposure to particulate matter inside buildings intended for animals. When it comes to people matters related to standards for particulate matter concentration are governed by the Directive CAFE (CAFE 2008). But in the case of animals we can base our assumptions only on the information included in the materials issued by the European Council regarding well-being, stating that the concentration of particulate matter in the buildings where the animals are housed must be maintained on the level that is not harmful to animals (The Council of the European Union. 1998). As far as legislation in Poland is concerned, standards for the maximum permitted PM concentration for animals have not been established yet. For people the average 24-h PM10 concentration cannot exceed $50 \mu \mathrm{g} / \mathrm{m} 3$ (powietrze.gios.gov.pl).

For that reason we have used in this paper standards established for people. In the studied period we recorded 11 days when PM10 concentration exceeded $50 \mu \mathrm{g} / \mathrm{m}^{3}$ and 24 days when PM2.5 was higher than $25 \mu \mathrm{g} / \mathrm{m}^{3}$ inside the antelope house.

The measurements taken indicated that despite fitting air filters in the ventilation system, particulate matter from the atmospheric air migrated into the building and the correlation coefficient between the concentration of particles indoors and outdoors was statistically significant. The building with its ventilation system reduced PM10 concentration by approximately $60 \%$ during the highest smog level as compared with the ambient air. Despite considerable reduction, the concentration of particulate matter inside the building exceeded the standard established for people (CAFE 2008) more than twofold. The research conducted by Wenke et. al. (2018) inside the building intended for animals with different ventilation systems and filter types demonstrated that the difference between particulate matter concentration in rooms with and without filters amounts to $10 \pm \mathrm{g} / \mathrm{m}^{3}$ on average. Challoner and Gill (2014) and Massey et. al. (2009) report that efficient reduction of particulate content by means of mechanical or natural ventilation in buildings intended for people is not possible.

The increase of PM concentration between 7:00 and 9:00 (Fig. 7) as well as 7:00 and 8:00 (Fig. 8) was most probably associated with cleaning and replacing litter, what resulted in additional PM increment inside the building.

The number of particles transported with the air inside the respiratory system depends on, among others, the volume of the air inhaled by the animal, that is pulmonary capacity reduced by so- 
256 called respiratory dead space. For the Defassa waterbucks the volume of inhaled air amounts to 257 approximately $9 \mathrm{dm}^{3}$, for addaxes $6 \mathrm{dm}^{3}$ and $4 \mathrm{dm}^{3}$ for lowland nyalas (Muir \& Hubbell 2012). 258 Assuming that the average number of breaths per minute for these animals in resting state 259 amounts to 25 , we are able to estimate that in the period with the highest particle concentration $260\left(\mathrm{PM} 10=118 \mu \mathrm{g} / \mathrm{m}^{3}, \mathrm{PM} 2.5=100 \mu \mathrm{g} / \mathrm{m}^{3}\right)$ the antelopes introduced into the respiratory system 261 approximately $1062 \mu \mathrm{g}$ of PM10 including $900 \mu \mathrm{g}$ of PM 2.5. It should be noted that these values are accurate only if we assume that animals were in resting state. Undertaking physical activities is associated with increasing the volume of inhaled air (increased depth of breathing and the number of breaths per minute).

265

266

267

268

269

270

271

272

273

274

275

276

277

278

279

280

281

282

283

284

285

286

287

288

289

290

During breathing PM2.5-10 migrate into the tracheal and bronchial part of the respiratory system, while PM2.5 reach lungs and through the cardiovascular system may be distributed throughout the body (Wei et. al. 2018, WHO 2013). The measurements taken in the building under the study revealed that as much as $85 \%$ of the particulate mass constitutes PM2.5. Migration of the particulate matter inside the antelope house is also associated with introducing other substances, among others, benzo(a)pyrene $(\mathrm{BaP})$, lead $(\mathrm{Pb})$, arsenic $(\mathrm{As})$, cadmium $(\mathrm{Cd})$, nickel (Ni) (Wróbel et al. 2000). Taking into account the average concentration of these substances in the ambient air in the period with the heaviest smog emission (Report 2018) as well as the reduction of the particulate matter quantity by the building, it is possible to calculate that the antelopes inside the facility introduced to their bodies through the respiratory system: $94,59 \mathrm{ng} / \mathrm{m}^{3} \mathrm{BaP}, 0,18 \mu \mathrm{g} / \mathrm{m}^{3} \mathrm{~Pb}, 10,62 \mathrm{ng} / \mathrm{m}^{3} \mathrm{As}, 8,91 \mathrm{ng} / \mathrm{m}^{3} \mathrm{Cd}$ and 4,5ng/m $/ \mathrm{m}^{3} \mathrm{Ni}$ per hour.

The negative correlation between the outside air temperature and the concentration of particulate matter indoors indicates that a decrease of temperature is followed by an increase in the quantity of burned fossil fuels used to heat houses, what in turn has influence on the level of particles in the atmospheric air. Particles generated in that way are transported through the ventilation system inside the buildings.

The discussion on the air pollution inside the antelope house should also cover the aspects connected with people involved in handling animals. During 8-hour working day at the highest particulate concentration these people inhale on average approximately $1173 \mu \mathrm{g}$ of PM10, including $972 \mu \mathrm{g}$ of PM 2.5 (Pocock et al. 2013).

Trees are capable of reducing particulate matter concentration (Sæbø et al. 2012). Despite the fact that the antelope house is surrounded by forest complexes filtering polluted air, the amount of PM produced by two neighboring towns (Chorzów and Katowice) is so large that it is impossible for the plants growing around the antelope house to efficiently clean the air $(>50$ $\mu \mathrm{g} / \mathrm{m} 3$ ) in the vicinity of the building (Fig. 4, red line).

\section{Conclusions}


291 The experiment revealed that the quantity of particulate matter inside the building intended for

292

293

294

295

296

297

298

299

300

301

302

303

304

305

306

307

308

309

310

311

312

313

314

315

316

317

318

319

320

321

322

323

324

antelopes is strongly correlated with the concentration of particles in the atmospheric air. In spite of the fact that the existing ventilation system is equipped with a reduction filter that lowers the dust level by $60 \%$ during the heaviest smog, particulate matter concentration in the antelope house exceeded acceptable limit for PM10 more than twofold. Particle size-fraction analysis revealed that as much as $85 \%$ of the particles identified in the studied building constitute PM2.5. These particles are capable of penetrating into the lungs causing its irritation or damage, as well as infiltrate through pulmonary alveolars into the vascular system. These results indicate that it is necessary to install suitable filters in the air supply ducts that would efficiently reduce the level of PM in air supplied from outside. The results obtained in the course of this study also indicate a strong need to conduct further research into the quality of air inside the facilities intended for animals as well as necessity to establish permissible particulate matter concentrations for farm, exotic and household animals.

\section{Acknowledgements}

Special thanks to the management and employees of the Silesian Zoological Garden in Chorzów for the opportunity to conduct research at the $\mathrm{ZOO}$.

\section{References}

CAFE 2008. CAFE DIRECTIVE 2008/50/EC OF THE EUROPEAN PARLIAMENT AND OF THE COUNCIL of 21 May 2008 On ambient air quality and cleaner air for Europe.

Challoner A, Gill L. 2014. Indoor/outdoor air pollution relationships in ten commercialbuildings: PM2.5 and NO2. Building and Environment 80: 159-173 DOI 10.1016/j.buildenv.2014.05.032

Chen C, Wang P, Chen Z, S, Wan Y, Wang Y, Zhao L. 2016. Impact of different structure characteristics of external windows on indoor pm 2.5 concentrations under infiltration ventilating. Journal of Beijing University of Technology 42:601-608. DOI 10.11936/bjutxb2015040019

Chen F, Lin Z, Chen R, Norback D, Liu C, Kan H, Deng Q, Huang C, Hu Y, Zou Z, Liu W, Wang J, Lu C, Qian H, Yang X, Zhang X, Qu F, Sundell J, Zhang Y, Li B, Sun Y, Zhao Z. 2018. The effects of $P M 2.5$ on asthmatic and allergic diseases or symptoms in preschool children of six Chinese cities, based on China, Children, Homes and Health (CCHH) project.

Environmental pollution 232:329-337 DOI 10.1016/j.envpol.2017.08.072.

Peer) reviewing PDF | (2019:11:42758:2:0:NEW 31 Mar 2020) 
Collins ER. 1990. Ventilation of sheep and goat barns. The Veterinary clinics of North America. Food animal practice 6:635-654. DOI 10.1016/S0749-0720(15)30837-9

Grimm H, Eatough DJ. 2009. Aerosol Measurement: The use of optical light scattering for the determination of particulate size distribution, and particulate mass, including the semi-volatile fraction. Journal of the Air \& Waste Management Association 59:101-107 DOI 10.3155/10473289.59.1.101.

Hazari MS, Haykal-Coates N, Winsett DW, Costa DL, Farraj AK. 2009. A single exposure to particulate or gaseous air pollution increases the risk of aconitine-induced cardiac arrhythmia in hypertensive rats. Toxicological sciences 112:532-42.39 DOI 10.1093/toxsci/kfp214.

Hinchcliff KW, Geor RJ, Kaneps AJ. 2008. Equine Exercise Physiology. The Science of Exercise in the Athletic Horse Book. Elsevier Ltd.

\section{Hulin V, Bernard P, Vorimore F, Aaziz R, Cléva D, Robineau J, Durand B, Angelis L,} Siarkou VI, Laroucau K. 2015. Assessment of chlamydia psittaci shedding and environmental contamination as potential sources of worker exposure throughout the mule duck breeding process. Applied and environmental microbiology. 28;82(5):1504-1518 DOI 10.1128/AEM.03179-15.

King C, Kirkham J, Hawcutt D, Sinha I. 2018. The effect of outdoor air pollution on the risk of hospitalisation for bronchiolitis in infants: a systematic review. PeerJ 6: e5352.DOI 10.7717 peerj.5352

Lim SS, Vos T, Flaxman AD, Danaei G at. al. 2012. A comparative risk assessment of burden of disease and injury attributable to 67 risk factors and risk factor clusters in 21 regions, 19902010:a systematic analysis for the Global Burden of Disease Study 2010. Lancet 380:2224-2260 DOI 10.1016/S0140-6736(12)61766-8.

Magrin L, Brscic M, Lora I, Rumor C, Tondello L, Cozzi G, Gottardo F. 2017. Effect of a ceiling fan ventilation system on finishing young bulls' health, behaviour and growth performance. Animal 11:1084-1092 DOI 10.1017/S1751731116002482

Massey D, Masih J, Kulshrestha A, Habila M, Tanejaa A. 2009. Indoor/outdoor relationship of fine particles less than $2.5 \mu \mathrm{m}$ (PM2.5) in residential homes locations in central Indian region. Building and Environment 44: 2037-2045 DOI 10.1016/j.buildenv.2009.02.010

Mołocznik A. 2004. Time of farmers' exposure to biological factors in agricultural working environment. Annals of agricultural and environmental medicine 11:85-89.

Muir W, Hubbell J. 2012. Handbook of Veterinary Anesthesia 5th Edition.

Polivka BJ. 2018. The Great London Smog of 1952. The American journal of nursing118:57-61. DOI 10.1097/01.NAJ.0000532078.72372.c3. 
359 Poulopoulos SG. 2016. Atmospheric Environment in Environment and Development, Elsevier 360 45-136. DOI 10.1016/C2012-0-07133-5

361 Perera FP, Illman SM, Kinney PL, Whyatt R, Kelvin EA, Shepard P. 2002. The challenge of preventing environmentally related disease in young children: community-based research in New York City. Environmental Health Perspectives 110:197-204 DOI 10.1289/ehp.02110197.

364

365

366

367

368

369

370

371

372

373

374

375

376

377

378

379

380

381

382

383

384

385

386

387

388

389

390

Pocock G, Richards DA, Richards CD. 2013. Human Physiology. Oxford University Press Fourth edition

Pope CA, Burnett RT, Thun MJ, Calle EE, Krewski D, Ito K, Thurston GD. 2002. Lung cancer, cardiopulmonary mortality, and long-term exposure to fine particulate air pollution. Journal of the American Medical Association 287:1132-1141 DOI 10.1001/jama.287.9.1132.

Qi M, Zhu X, Du W, Chen Y, Chen Y, Huang T, Pan X, Zhong Q, Sun X, Zeng EY, Xing B, Tao S. 2017. Exposure and health impact evaluation based on simultaneous measurement of indoor and ambient PM2.5 in Haidian, Beijing. Environmental pollution 220:704-712 DOI 10.1016/j.envpol.2016.10.035.

Report. 2018. State of the environment in the Silesia Province in 2017 (in polish). Environmental Monitoring Library Katowice

Routledge HC, Ayres JG. 2005. Air pollution and the heart. Occupational Medicine 55:439-447 DOI10.1093/occmed/kqi136.

Sabø A, Popek R, Nawrot B, Hanslin HM, Gawronska H, Gawronski SW. 2012. Plant species differences in particulate matter accumulation on leaf surfaces. The Science of the total environment. 427-428:347-54. DOI 10.1016/j.scitotenv.2012.03.084.

Seinfeld JH, Pandis SN. (2006). Atmospheric Chemistry and Physics: From Air Pollution to Climate Change. 2nd Edition, John Wiley \& Sons, New York.

Selevan SG, Borkovec L, Slott VL, Zudová Z, Rubes J, Evenson DP, Perreault SD. 2000. Semen quality and reproductive health of young Czech men exposed to seasonal air pollution. Environmental Health Perspectives. 108:887-94 DOI 10.1289/ehp.00108887.

Stafford KJ, Stafford YM. 1993. The anatomy of the omasum of some Zambian game species. Anatomia, histologia, embryologia 22:342-7 DOI: 10.1111/j.1439-0264.1993.tb00229.x

Tainio M, Juda-Rezler K, Reizer M, Warchałowski A, Trapp W, Skotak K. 2013. Future climate and adverse health effects caused by fine particulate matter air pollution: case study for Poland. Regional Environmental Change 13: 705-715

The Council of the European Union. 1998. COUNCIL DIRECTIVE 98/58/EC 
391

392

393

394

395

396

397

398

399

400

401

402

403

404

405

406

407

408

409

410

411

412

413

414

415

416

417

418

419

Veasey JS. 2017. In pursuit of peak animal welfare; the need to prioritize the meaningful over the measurable. Zoo biology 36:413-425 DOI 10.1002/zoo.21390.

Wei Y, Cao XN, Tang XL, Shen LJ, Lin T, He DW, Wu SD, Wei GH1. 2018. Urban fine particulate matter (PM2.5) exposure destroys blood-testis barrier (BTB) integrity through excessive ROS-mediated autophagy. Toxicology mechanisms and methods 28:302-319 DOI 10.1080/15376516.2017.1410743

Wenke C, Pospiech J, Reutter T, Altmann B, Truyen U, Speck S. 2018. Impact of different supply air and recirculating air filtration systems on stable climate, animal health, and performance of fattening pigs in a commercial pig farm. PLoS One 13 e0194641 10.1371/journal.pone.0194641.

WHO. 2013. Health effects of particulate matter. Policy implications for countries in eastern Europe, Caucasus and central Asia. World Health Organization, Regional Office for Europe, Copenhagen.

WHO. 2006. Air quality guidelines for particulate matter, ozone, nitrogen dioxide and sulfur dioxide: global update 2005: summary of risk assessment. World Health Organization, Geneva.

Wróbel A, Rokita E, Maenhaut W. 2000. Transport of traffic-related aerosols in urban areas. The Science of the Total Environment 257:199-211 DOI 10.1016/S0048-9697(00)00519-2.

Yi L, Wei C, Fan W. 2017. Fine-particulate matter (PM2.5), a risk factor for rat gestational diabetes with altered blood glucose and pancreatic GLUT2 expression. Gynecological endocrinology 33: 611-616 DOI 10.1080/09513590.2017.130192

Zanobetti A, Bind MA, Schwartz J. 2008. Particulate air pollution and survival in a COPD cohort. Environ Health 7:1-9 DOI 10.1186/1476-069X-7-48.

http://www.gios.gov.pl/stansrodowiska/gios/pokaz_artykul/en/front/stanwpolsce/srodowisko_i_z drowie/zanieczyszczenia_powietrza/ - dostęp 21.03.2020 (in English)

https://powietrze.gios.gov.pl/pjp/content/annual_assessment_air_acceptable_level - dostęp 21.03.2020(in English) 
Figure 1

A fragment of the orthophotomap showing developments in the immediate vicinity of the antelope house. Taken based on the website www.geoportal.gov.pl .

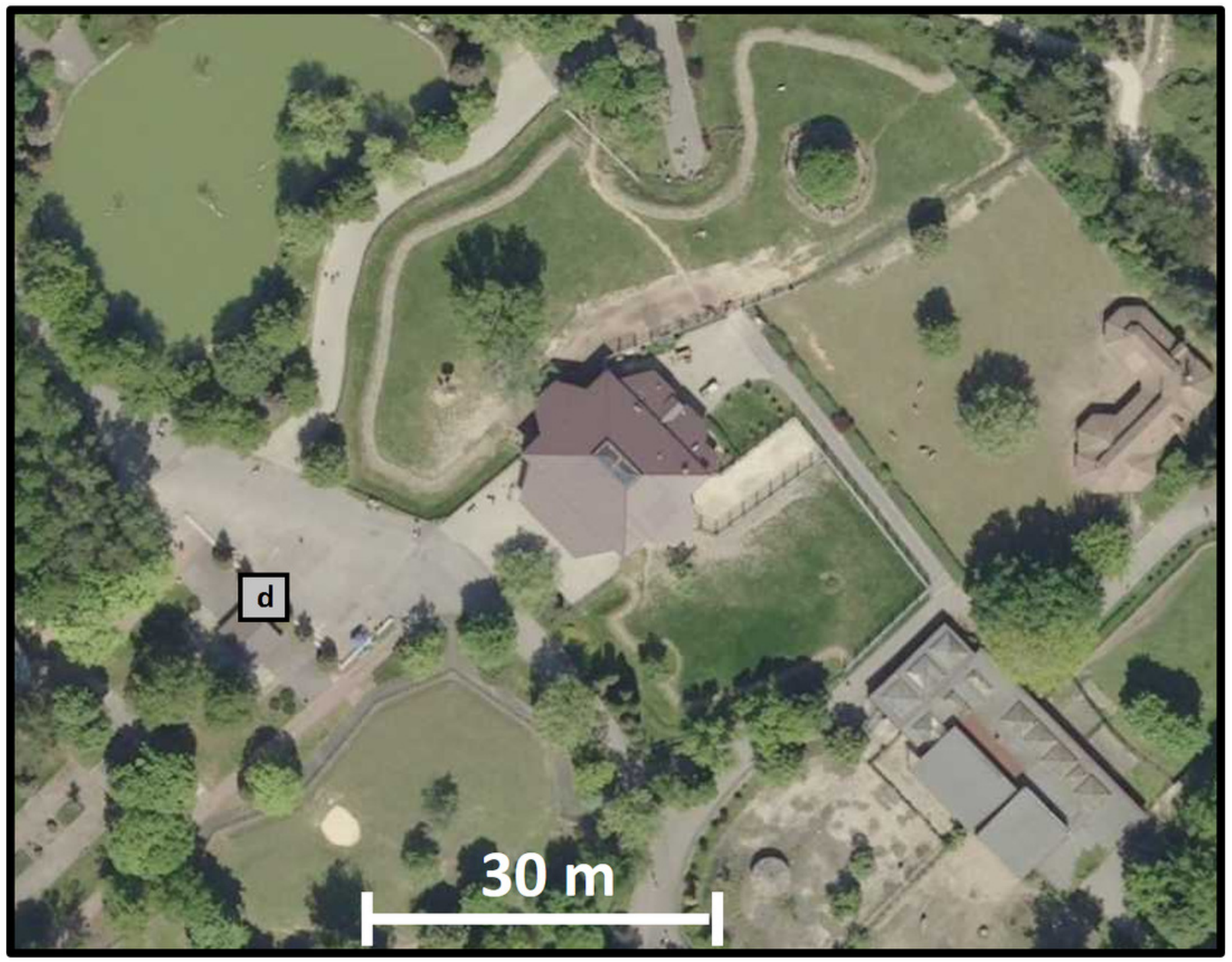


Figure 2

Building plan for antelopes

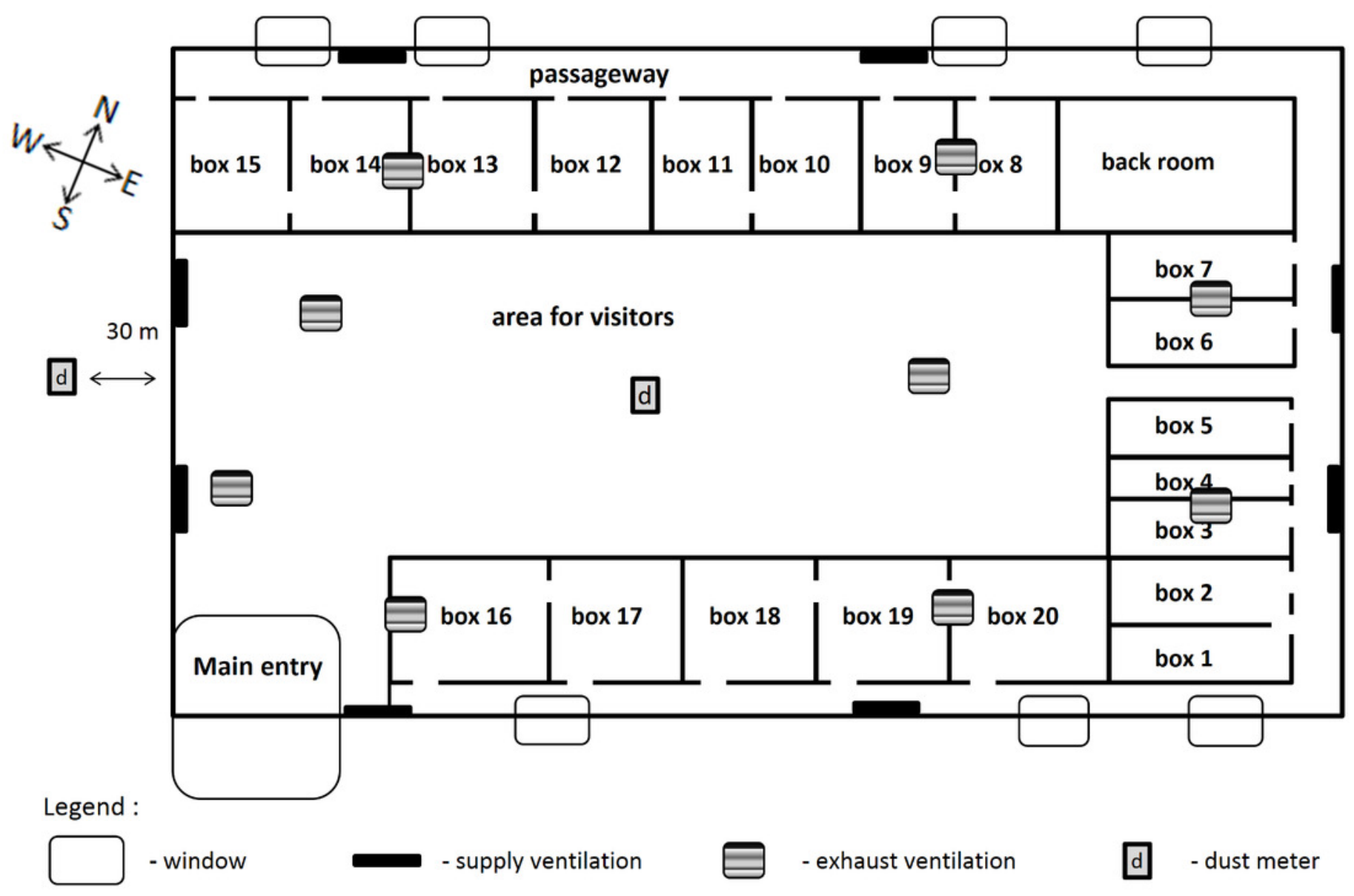


Figure 3

View of box (no. 15) with antelope

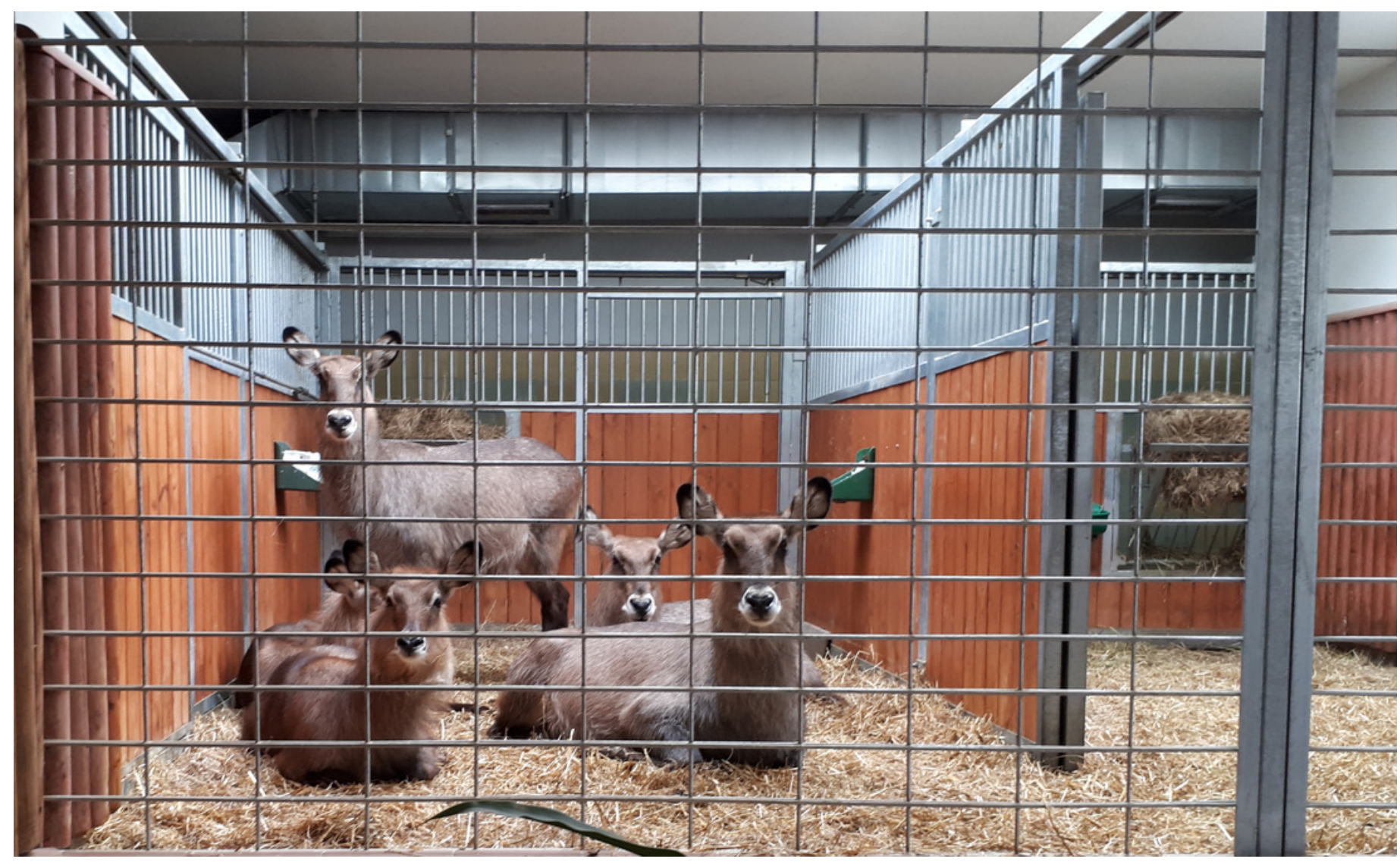


Figure 4

Distribution of daily average concentration for $\mathrm{PM}_{10}$ determined based on measurements taken inside (black) and outside (red) the antelope house in the period from 27.02.2018 to 16.05 .2018 .

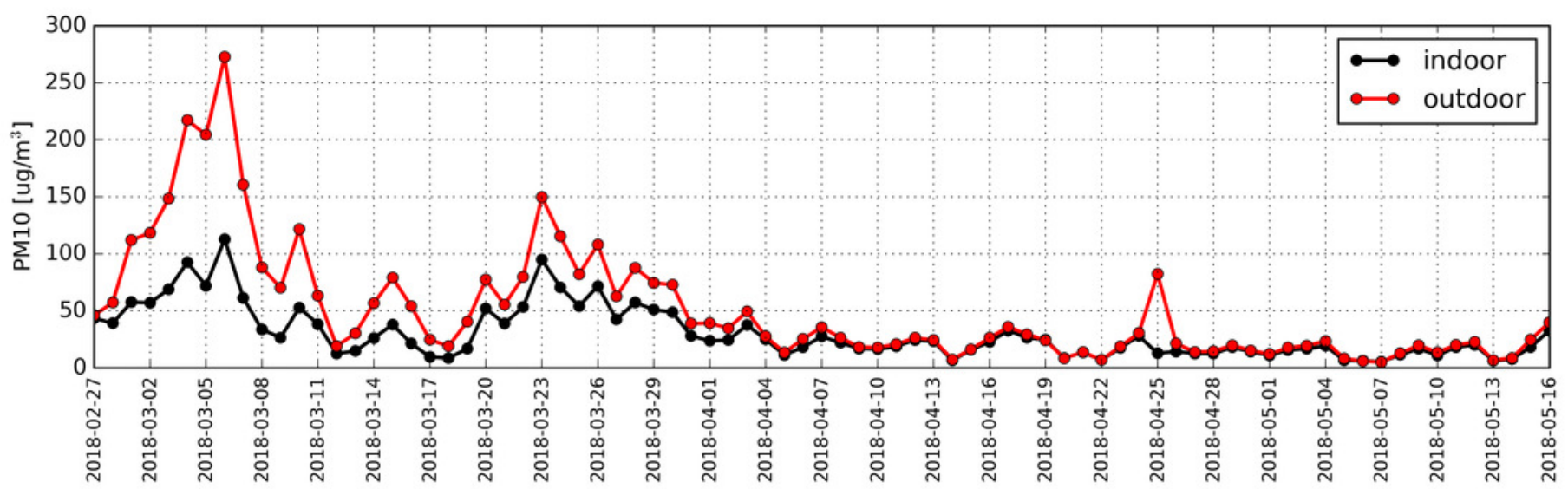


Figure 5

Distribution of daily average concentration for $\mathrm{PM}_{2.5}$ determined based on measurements taken inside (black) and outside (red) the antelope house in the period from 27.02.2018 to 16.05.2018.

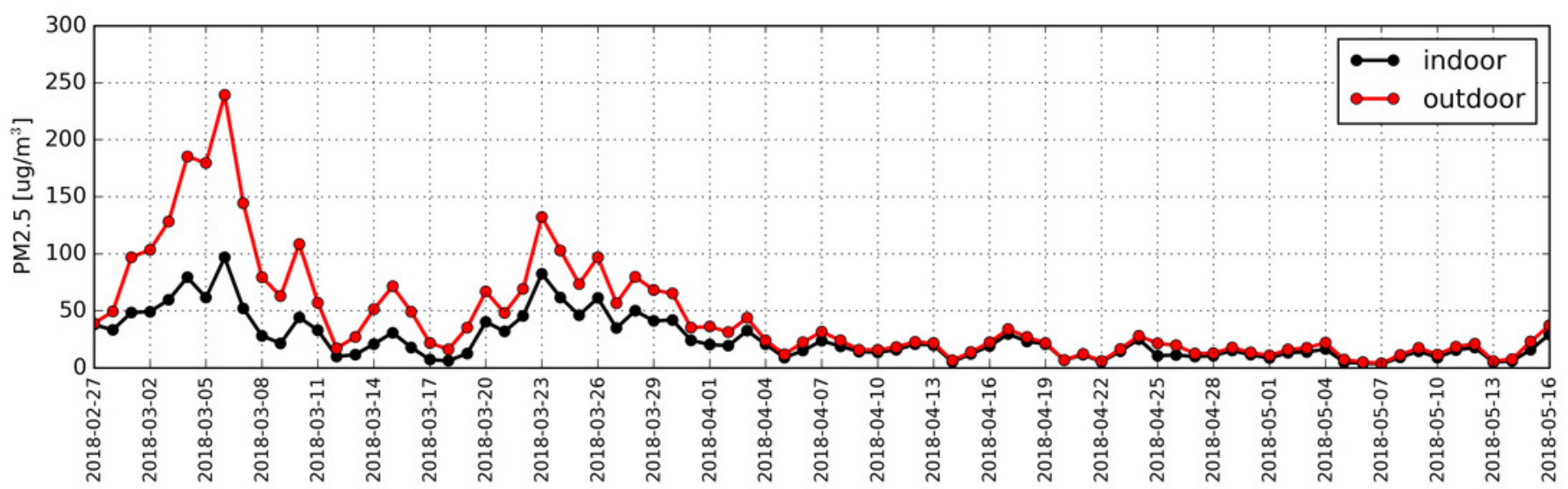


Figure 6

Distribution of daily reduction factor (RF) for $\mathrm{PM}_{10}$ calculated based on measurements taken inside and outside the antelope house in the period from 27.02.2018 to 16.05.2018.

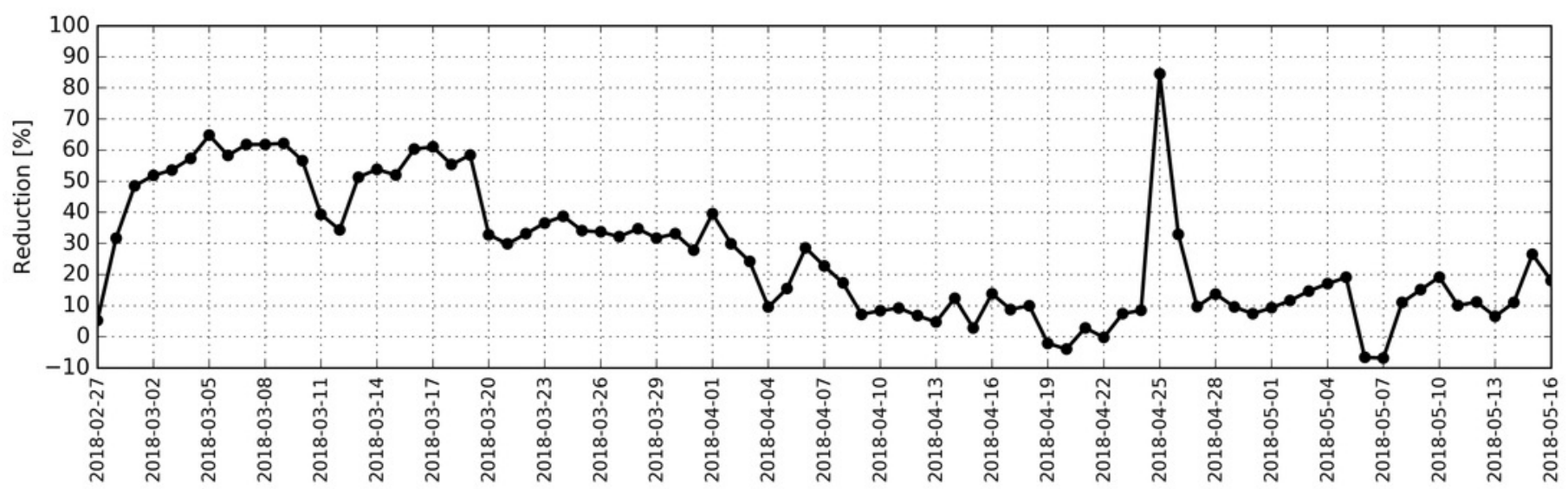


Figure 7

Distribution of daily average PM concentration inside (black) and outside (red) the antelope house based on hourly average for $\mathrm{PM}_{10}$ recorded from 27.02.2018 to 03.04.2018, that is in the period of high PM concentration in the atmospheric air.

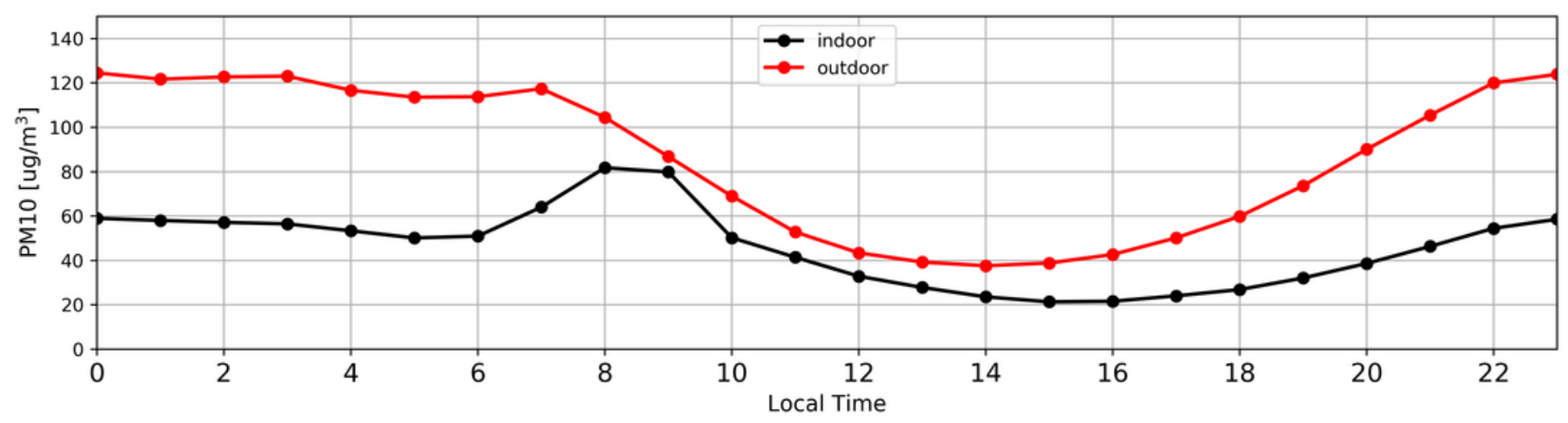


Figure 8

Distribution of daily average PM concentration inside (black) and outside (red) the antelope house based on hourly average for $\mathrm{PM}_{10}$ recorded from 04.04.2018 to 16.05.2018, that is in the period of low PM concentration in the atmospheric air.

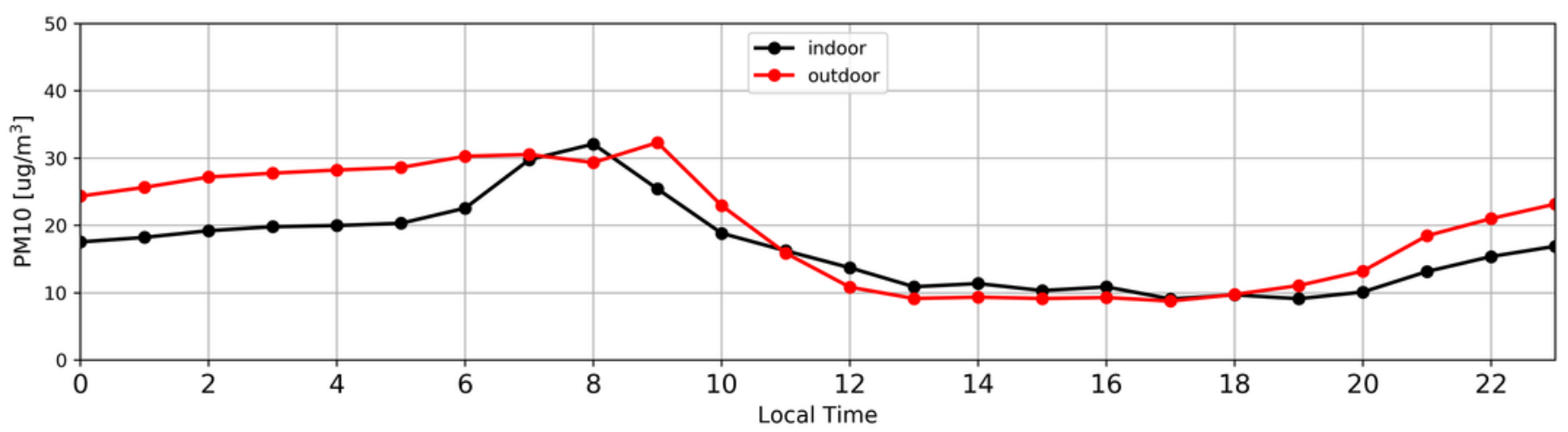


Figure 9

Distribution of $\mathrm{PM}_{10}$ ( 1 min resolution) determined based on measurements taken inside (black) and outside (red) the antelope house in the period from 03.03.2018 to 04.03.2018.

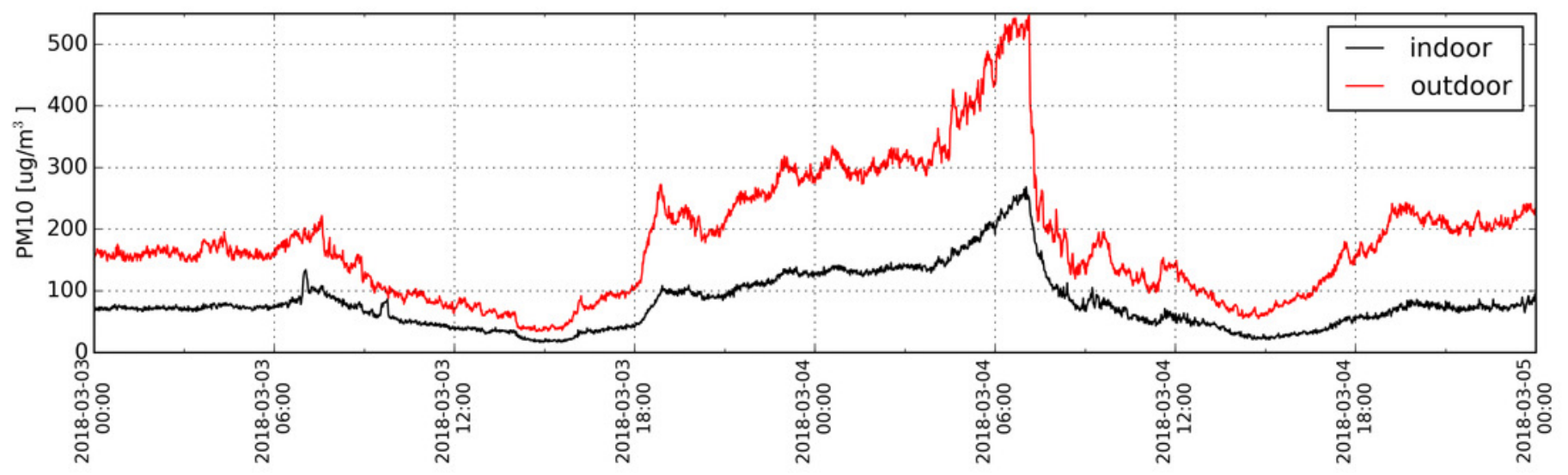


Figure 10

Distribution of daily average temperatures determined based on measurements taken inside (black) and outside (red) the antelope house in the period from 27.02.2018 to 16.05.2018.

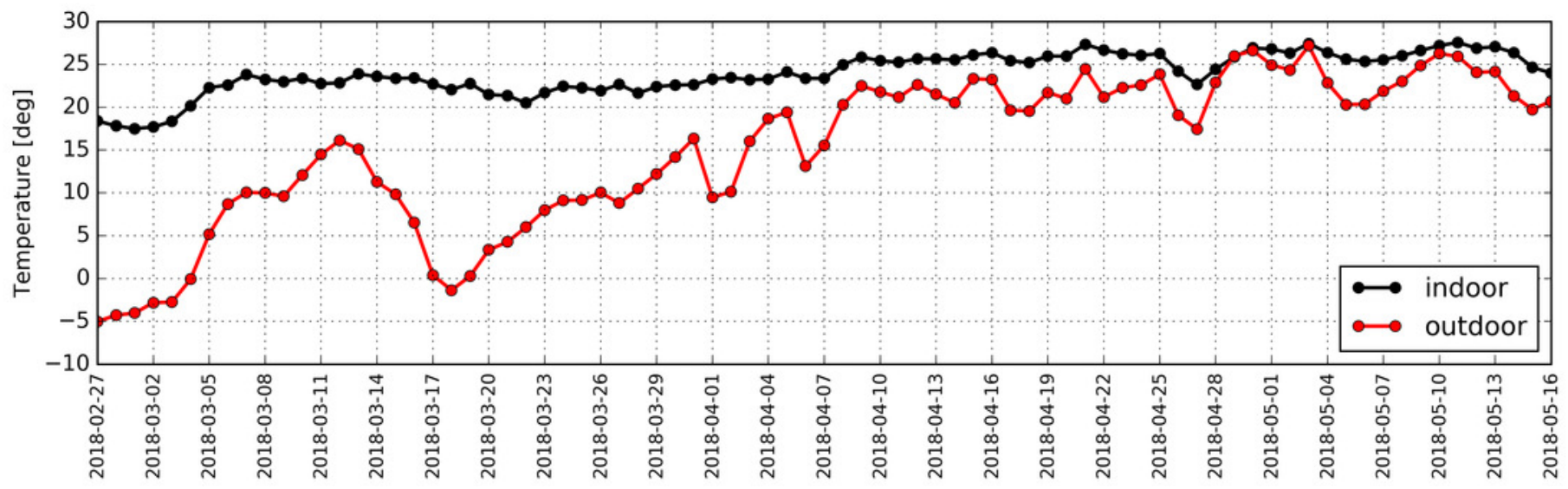


Figure 11

Distribution of daily average relative humidity determined based on measurements taken inside (black) and outside (red) the antelope house in the period from 27.02.2018 to 16.05 .2018 .

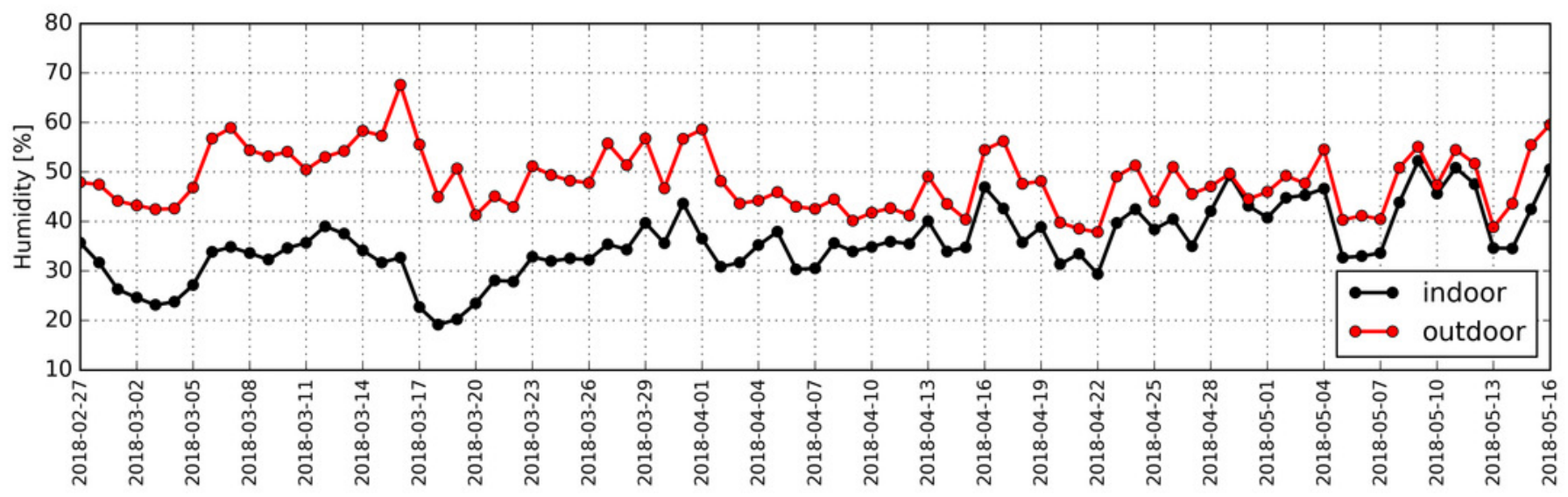


Figure 12

Distribution of daily average air pressure determined based on measurements taken in the period from 27.02.2018 to 16.05.2018.

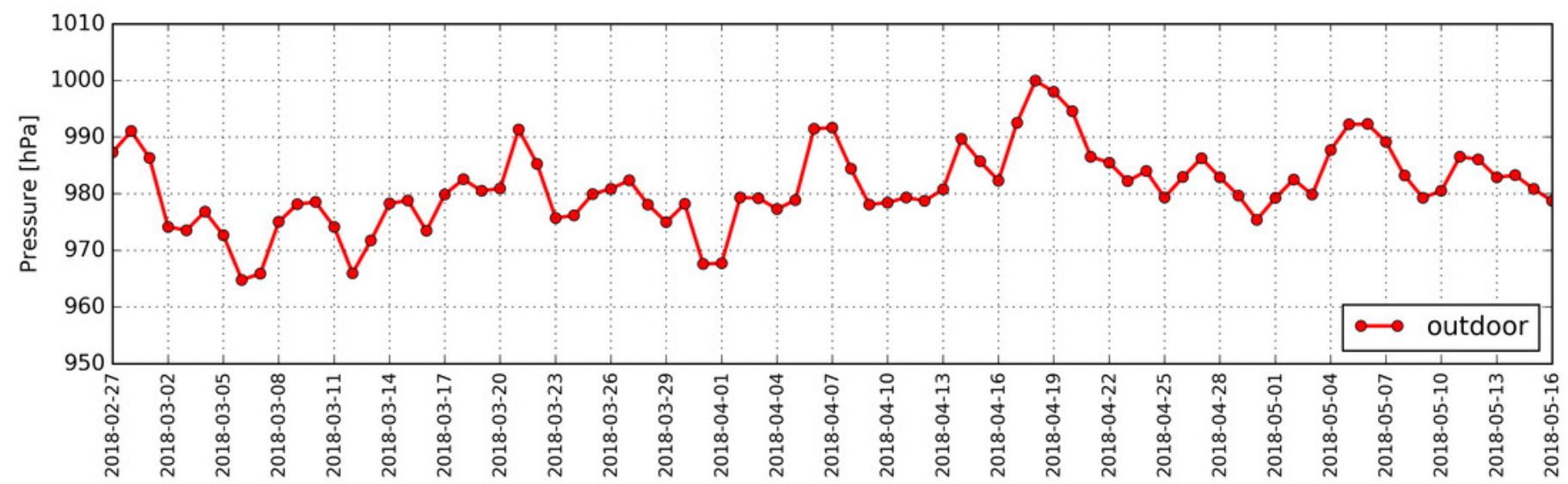

